\title{
BODY AS DANGER: GENDER, RACE AND BODY IN TONI MORRISON'S SULA
}

\author{
Pi-hua $\mathrm{Ni}^{*}$ \\ National Chiayi University \\ Chiayi City, Taiwan
}

\begin{abstract}
This paper aims at tackling the question as to why Sula as a social nonconformist and sexual dissident ends up as an avatar of evil, a powerless victim of witch-hunt and eventually a scapegoat for the decline and misfortunes of her community. To facilitate this critical task, this paper shall first apply Michel Foucault's genealogy of "the body as the bearer of pleasure and desire" as laid out in Abnormal to illustrate that Christian folks in Sula's community interpret Sula's nonconformity as evil and treat her as a danger to their social order. Thus, this paper argues that the black folks' ostracism of Sula betokens their mass hysteria and witch-hunt to exorcise their community of danger and evil. Moreover, this paper suggests that Sula is gendered and racialized as a black witch and symbolically executed. In conclusion, this paper contends that an identification of body with flesh, a phallocentric gender ideology and race bias converge into the black folk's association of Sula with a witch and a danger and their subsequent victimization of Sula as a scapegoat for all the misfortunes of their community.

Keywords: body politics; gender politics; Toni Morrison; Sula; witch, witch-hunt.
\end{abstract}

You can't do it all. You a woman and a colored woman at that. You can't act like a man. You can't be walking around all independent-like, doing whatever you like, taking what you want, leaving what you don't. Nel to the dying Sula in Sula, 142

\section{Introduction}

Scholarship pertaining to the theme of order/ disorder and good/evil in Toni Morrison's Sula tends to argue that the novel is the Nobel laureate's deconstruction of our dichotomous thinking. For instance, Rita A. Bergeholtz contends that Sula is a satire on binary thinking; Cedric Gael Bryant asserts that Morrison presents orderliness out of the disorder in the Bottom (the black community in Medallion) and thus turns the novel into a paradox on the good/evil binary; applying the Nigerian/West African concept of ogbanje-abiku (spirit-children) into his analysis of Sula, Christopher N. Okonkwo draws an equivalence between Sula and the ogbanje-abiku and elaborates on Sula's existential difference and her power of rebirth and making change. The foregoing critical assertions reflect what Mary Douglas has contended in Purity and Danger about the regenerative power of danger and evil. According to Douglas, every culture standardizes social values and mediates individual experience. To effect this purpose, it would provide basic categories and patterns for it to set values and order. Whenever the ordered pattern and values are challenged by the so called anomalies, "[a] ttributing danger is one way of putting a subject above dispute. It also helps to enforce conformity," writes Douglas (40). On the other hand, Douglas asserts that disorder serves paradoxically both as a threat and as a change to social order. Disorder provides fertile material and potential for new patterning:

\footnotetext{
* Pi-hua Ni has been full Professor of American and British Literature at the Department of Foreign Languages, National Chiayi University in Taiwan. With expertise in American and British fiction, gender studies and literary theories, Ni has published books and papers on contemporary women writers-particularly their re/visions of the androcentric literature and tradition, African American fiction and postmodern fiction.

Email:phni@mail.ncyu.edu.tw; pi_hua_ni@hotmail.com.
} 
Granted that disorder spoils pattern; it also provides the materials of pattern. Order implies restriction; from all possible materials, a limited selection has been made and from all possible relations a limited set has been used. So disorder by implication is unlimited, no pattern has been realized in it, but its potential for patterning is indefinite. This is why, though we seek to create order, we do not simply condemn disorder. We recognize that it is destructive to existing patterns; also that it has potentiality. It symbolizes both danger and power. (94)

Following this optimistic view, Douglas argues for the power of danger and maintains that the "polluting", dangerous person shall eventually effect, by destruction, change/s to any society demanding conformity: "The danger which is risked by boundary transgression is power. Those vulnerable margins and those attacking forces which threaten to destroy good order represent the powers inhering in the cosmos," writes Douglas (161). ${ }^{1}$ Given Douglas' assumptions, it is possible to suggest that Sula's rebellion against the social mores and norms shall bring about changes to her black community.

Yet, this critical vein finds itself at odds with the case of Sula and the community wherein she lives. Sula defies social mores and asserts sexual autonomy/ anarchy. In "Unspeakable Things Unspoken," Morrison fittingly describes her heroine Sula as a "dangerously female" who is "outlawed, unpolicing, uncontained and uncontainable" (390). At the same time, Sula's community, the Bottom, strives to maintain its order and refuses to contain Sula. Yet, Sula's defiance against social mores and moral norms makes her black folks call her first a roach, then a bitch and ultimately a witch-that is, an embodiment of evil and danger. In their collective fight against Sula, the town folks resort to complete rejection and ostracism of Sula. Therefore, the black folks welcome Sula's death as jubilantly as the people in the sixteenth, seventeenth century applauded the burning of a witch:

The death of Sula Peace was the best news folks up in the Bottom had had since the promise of work at the tunnel. Of the few who were not afraid to witness the burial of a witch and who had gone to the cemetery, some had come just to verify her being put away but stayed to sing 'Shall We Gather at the River' for politeness' sake, quite unaware of the bleak promise of their song. (150)

The bleak fact that Sula's betokening danger/evil does not effect any real positive change to the social values and her folks' mindset undermines the critical assumptions made by the aforementioned critics. That is, Sula's nonconformity is not accompanied with a regenerative power. Instead, Sula is victimized as a powerless lamb for the decline and all the other misfortunes in the Bottom. As bell hooks observes in Black Looks: Race and Representation:

Sula's death at an early age does not leave the
reader with a sense of "power," instead she seems
powerless to assert agency in a world that has
no interest in radical black female subjectivity,
one that seeks to repress, contain, and annihilate
it. ${ }^{2}$ Sula is annihilated. The reader never knows
what force is killing her, eating her from the
inside out. [...] Sula's fate suggests that charting
the journey of radical black female subjectivity
is too dangerous, too risky. And while Sula
is glad to have broken the rules, she is not a
triumphant figure. (48)

Instead of being a changing force and regenerative power, Sula is de facto a powerless social nonconformist and sexual dissident.

To tackle the question why Sula as a social and sexual dissident ends up as an avatar of evil, a powerless victim of witch-hunt and eventually a scapegoat for the decline and misfortunes of her community, this paper shall apply Michel Foucault's genealogy of "the body as the bearer of pleasure and desire" as explained in Abnormal to illustrate that Christianized folks in the Bottom interpret Sula's social dissidence and sexual emancipation as evil and treat her as a threat to their social order (192). In Foucault's terms, Sula's body is made flesh, abnormal, evil and thus a danger to the community. Thus said, this paper argues that Sula's community fights not just against Sula but, above all, against "the body made flesh," a black Byronic 
heroine and a black witch. The black folks' ostracism of Sula betokens their moral panic, mass hysteria and witch-hunt to exorcise their community of danger and evil. Moreover, this paper suggests that different body politics for man and woman determine different identity politics. Sula and Ajax are alike in practicing sexual anarchy and defying social mores. Nevertheless, Sula's revolt threatens her community and incurs danger to herself, whereas Ajax can walk away free of trouble. In the same vein, all the husbands who betray their wives and commit adultery with Sula are not in the least condemned by their town folks. Accordingly, the novel foregrounds the fact that androcentric gender ideology is complicit with designating different lives and fates for Sula and Ajax and, by extension, for the female and male sexual "monsters." Therefore, Sula's body is a gendered body. Thirdly, this paper contends that race politics also comes into play with the determination of Sula's fate. Sula is deemed the filthiest because she goes to bed with white men - an affront to the black men of Sula's community. Sula as a black woman is NOT allowed to go to bed with white men albeit some of Sula's male folks have had sex with her and some others dream to make love to her. Moreover, black men do not mind that they bed down with white women whereas they cannot tolerate Sula sleeping with white men. In this sense, Sula's body is a racialized body. Therefore, the black men in the Bottom join the witch-hunt to exorcise their community of Sula in the hope that their community will stop suffering from an ongoing decline once the evil spirit is gone. Based on the foregoing assertions, this paper concludes that an identification of body with flesh, a phallocentric ideology and race bias converge into the black folk's association of Sula with a witch and a danger and their subsequent victimization of Sula as a scapegoat for all the misfortunes of their community.

\section{Flesh-ized Body as Evil and Danger}

A discussion of Foucault's genealogy of "abnormality" will help us understand how societal demand of morality, order and conformity sets the flesh-ized body as danger. Foucault's genealogy will also make us recognize that whenever a social nonconformist or a sexual dissident challenges norms and infringes on morality, $\mathrm{s} / \mathrm{he}$ is prone to be tagged as a dangerous individual. Then, doom is looming for this dangerous individual.

In his study of man's control and normalization of daily life sexuality, Foucault allocates the practice of the sixteenth-century Church confession as an important shift in our cognition and definition of the sin of lust and thus as the starting point which constitutes the body as flesh, evil and, finally, dangerous. Before the sixteenth century, the sin of lust is delimited in the relational aspect of sexuality. That is, one commits the sin of lust when s/he has any illegitimate or immoral sexual relationship with someone else. With the advent of the new examining technique of the sixteenth-century Church confession, the Church's questioning focuses on the movements, senses, pleasures, thoughts, and desires of the penitent's body. Of this new examination, Foucault writes:

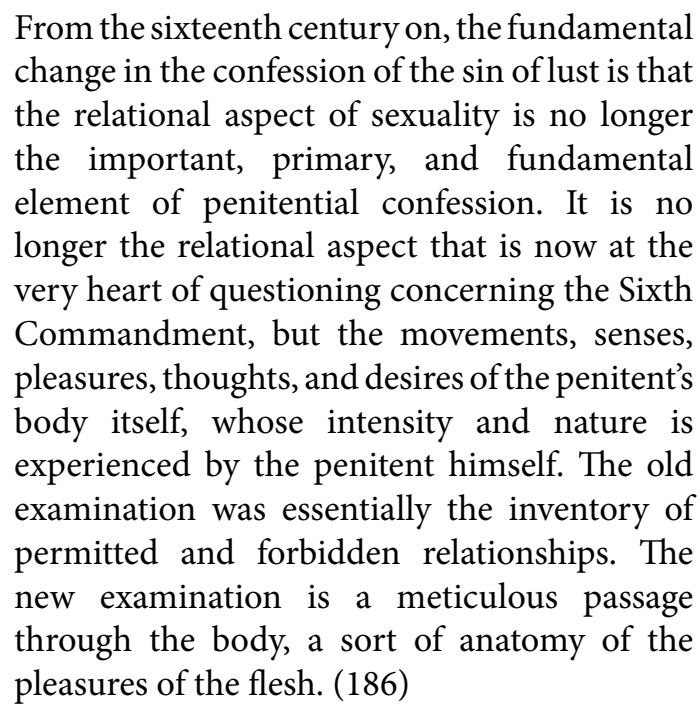

Thus said, the body is deemed "the bearer of pleasure and desire." Accordingly, the sin of flesh is focused on the body and the flesh is pinned to the body. The body is made flesh and evil. Foucault expounds this identification as follows:

[A]round these procedures of penitential confession, there is an identification of the body and the flesh or, if you like, the body is made flesh and flesh is incorporated in a body (une incarnation $d u$ corps et une incorporation de la chair), which brings to light the original 
game of desire and pleasure at the point where soul and body meet, in the space of the body and at the very root of consciousness. (192)

With this new concept of the flesh-ized body, any individual is liable to be made an avatar of evil as long as $\mathrm{s} /$ he does not follow norms.

Furthermore, Foucault explains that morality plays a key role in the formation of this new definition and constitutes the backbone of the discourses on "norm" and "abnormal." The French philosopher argues that the discourse on "norm" is de facto an attempt to detect and counter social danger:

And, from a different angle, it is a discourse not only organized around the field of perversity, but also around the problem of social danger. That is to say, it will also be a discourse of fear and moralization, a childish discourse, a discourse whose epistemological organization, completely governed by fear and moralization, can only be derisory, even regarding madness. (35)

Apparently, the ideas of the flesh-ized body and the dangerous individual are derived from societal demand of morality and conformity. A rebellious individual would be dubbed "nasty," "perverted," "abnormal," and seen as a "danger" if s/he defies the norms.

To foil the potentiality of the flesh-ized and dangerous individual and to safeguard social mores and order, new mechanisms of normalizing power are invested upon the body in order to render it docile. This process of normalization and moralization begins with the regulation and formation of the child's body and sexuality. In Abnormal Foucault maintains that the family serves as an effective and powerful institution to control, discipline and normalize an individual's body and sexuality since childhood:

Actually, the family space must be a space of continual surveillance. Children must be watched over when they are washing, going to bed, getting up, and while they sleep. Parents must keep a lookout all around their children, over their clothes and bodies. The child's body must be the object of their permanent attention. This is the adult's primary concern. (245)
Thus, the family becomes the space of surveillance and serves as an important source of normalization to educate their children to follow norms. Nevertheless, the Peace family in Morrison's Sula presents a reversal of this mechanism of normalization and moralization.

In the traditional view, the Peace family is an "anomaly" since parental surveillance over and discipline of the child's body are entirely absent. Hannah is a young widow. Though Hannah does not want to establish any committed relationship with a man, she desires a man's touching every day. That is, Hannah has/provides free sex with/to any man and makes herself "a role model" of female sexual autonomy for Sula. It is not Hannah who keeps lookouts on Sula (the child); instead, it is Sula who constantly keeps her gaze on Hannah and learns about the secret joy of flesh. Therefore, Sula's body is not disciplined and regulated to follow "norms." On the contrary, Sula follows her mother's suit and even pushes it to the extreme to make herself a social nonconformist, a sexual anarchist and a religious blasphemer. Sula's social, moral and sexual defiance makes her town folks flesh-ize Sula's body and identify her with evil and danger. Consequently, Sula is deemed by the Christianized black community an evil witch who is to blame for all the misfortunes-both individual and collective-in the Bottom. Sula's black folks therefore must exorcise their community of the witch/danger in the hope that Sula's crush/death shall bring them good luck-for instance, solve their serious problem of unemployment and avert an ongoing decline in their community.

The following sections shall illustrate that: (1) in the Peace household, Hannah does not endeavor to fulfill the family function of disciplining Sula into following norms and mores about sex; instead, Hannah asserts sexual autonomy and subconsciously initiates Sula to explore and enjoy the pleasure of flesh; (2) Hannah's claim of disliking Sula and Sula's accidental killing of Chicken Little lead Sula to develop a nihilistic philosophy toward life and subsequently to express her nihilism in sexual anarchy, immorality, social nonconformity and religious blasphemy; (3) the coincidental concurrence of Sula's libertine life and the decline and prolonged unemployment in her black 
community, the Bottom, drive Sula's folks to believe that Sula is a witch and brings about all the misfortunesboth individual and collective-to her folks in the Bottom; (4) Sula's defiance against societal demand of morality and conformity creates the pretext for her black folks to flesh-ize her body as evil and dangerous and consequently to symbolically exorcise her in the form of complete ostracism; and (5) the flesh-ization of Sula's body turns out to be a gendered and racialized body - a result derived from the discrimination against a nonconformist black woman.

\section{Flesh-ized Sula as Evil and Dangerous}

Sula's mother, Hannah Peace, plays a crucial role in shaping Sula's philosophy toward sex and life. As a young widow, Hannah keeps a steady sequence of lovers without the least intention of marrying again. Moreover, Hannah does not mind that Sula is around when she is making love with her lovers. Hannah takes her lover down into the cellar, to the pantry, the parlor or even up to her bedroom where Sula sleeps. Of all the places for lovemaking in her house, Hannah likes her bedroom least not because she wants to carry out her parental duty to discipline Sula's body and sexuality but because she does not want to have any commitment to any man:

She liked the last place least, not because Sula slept in the room with her but because her love mate's tendency was always to fall asleep afterward and Hannah was fastidious about whom she slept with. She would fuck practically anything, but sleeping with someone implied for her a measure of trust and a definite commitment. (43-44)

Hannah's practice of sexual autonomy exerts great influence upon the development of Sula's sexuality. Witnessing Hannah's lovemaking and sexual pleasure since her childhood, Sula believes that sex is pleasant and frequent and makes up her mind to enjoy sex in her life:

Seeing her step so easily into the pantry and emerge looking precisely as she did when she entered, only happier, taught Sula that sex was pleasant and frequent, but otherwise unremarkable. Outside the house, where children giggled about underwear, the message was different. So she watched her mother's face and the face of the men when they opened the pantry door and made up her own mind. (44)

It is clear at this juncture that the Peaces take the desire and pleasure of the body as ordinary, normal and daily. Therefore, the Peace family does not observe the mechanisms of surveillance and discipline of a child's development of sexuality. Instead, they set themselves free of the moral and social constraints on sex.

The lovemaking scene of Sula with Ajax bears similarity to Hannah's with her lovers and thus foregrounds the realization of Sula's resolution to enjoy sex as her mother has done. Having learned of Sula's libertine sexual life and her ostracism by her folks in the Bottom, the libertine Ajax becomes interested in Sula and takes advantage of her unwillingness to keep any man. The very first time Ajax knocks at Sula's door, Sula takes him in. A brief mutual seducing soon stirs both of them. The way and the place(s) Sula makes love to Ajax echo exactly Hannah's lovemaking to her lovers:

She took the bottle with one hand and his wrist
with the other and pulled him into the pantry.
There was no need to go there, for not a soul was
in the house, but the gesture came to Hannah's
daughter naturally. There in the pantry, empty
now of flour sacks, void of row upon row of
canned goods, free forever of strings of tiny
green peppers, holding the wet milk bottle
tight in her arm she stood wide-legged against
the wall and pulled from his track-lean hips all
the pleasure her thighs could hold. (125)

Sula's deliberate imitation of her mother's lovemaking scene bespeaks what Sula has learned from her mother-a belief that sex is pleasure and joyful rather than evil and dangerous. Hannah as a mother sets sex free for Sula.

In moral and social contexts, Hannah's assertion of sexual autonomy makes herself a hazard to the women folks in the black community: 
Hannah exasperated the women in the townthe "good" women, who said, "One thing I can't stand is a nasty woman"; the whores, who were hard put to find trade among black men anyway and who resented Hannah's generosity; the middling women, who had both husbands and affairs, because Hannah seemed too unlike them, having no passion attached to her relationships and being wholly incapable of jealousy. (44)

Given her sexual patronage of men, Hannah cannot establish enduring friendship with women since her lovers are husbands of her friends, neighbors and even tenants. Yet, men of the black community defend Hannah. "The men, surprisingly, never gossiped about her. She was unquestionable, a kind and generous woman and that, coupled with her extraordinary beauty and funky elegance of manner, made them defend her and protect her from any vitriol that new comers or their wives might spill" (44-45). As a sexual patron, Hannah ironically has men's full support and escapes the fate of being deemed and condemned as an evil witch in her community.

On the other hand, Sula does not only follow her mother's suit in asserting sexual autonomy but also deliberately falls outside the norms in all aspects. Sula grows up to be a sexual dissident, a social nonconformist and moral transgressor. She defies all the traditional gender roles, challenges social mores, breaks moral norms and practices a radical sexual life. In so doing, Sula provokes not only the outrage of both men and women in the Bottom but also incurs an identification of her with a roach, a bitch and ultimately a witch. With her rebellions, Sula makes herself a black Byronic heroine.

After having left her hometown for college for ten years, Sula returns to the Bottom and is considered by her folks as a roach/bitch/witch for certain "reasons." First of all, Sula sneers at and refuses to play the traditional gender roles that a conservative patriarchal society demands of a woman. Sula's challenge to andocentric gender ideology is first manifested in her talk with her grandmother Eva. When Eva tells Sula that she should get married, have children and settle down, Sula makes her self-assertion by telling Eva that she just wants to be herself: “I don't want to make somebody else. I want to make myself" (92). Secondly, Sula rejects the gender role for a woman to be the caretaker of an elderly. Sula enrages her folks because she dumps Eva first as a lunatic in an asylum run by the white church out by Beechnut and, accepting Nel's admonition, transfers Eva to the nursing home Sunny dale. Since then, Sula completely neglects Eva. "When the word got out about Eva being put in Sunny dale, the people at the Bottom shook their heads and said Sula was a roach" (112). Thirdly, it is not only that Sula refuses to make herself "the angel in the house" 3 but also that she aspires to be a man and do whatever a man is allowed to do. The most reprehensible thing for a woman to do-but acceptable for a man-is sexual liberation. But Sula deliberately defies this constraint for women. With her anarchist experiments with social mores and moral norms, Sula sleeps with any man. Sula even takes Jude, the husband of Sula's best friend Nel. Since then, Sula's folks call her a bitch; but ironically they sympathize with Jude. Seven years after their friendship has broken off, Nel visits Sula when the friendless and lonely overreacher lies dying. Nel's comment on Sula's life provides an insightful review of the sexual anarchist's philosophy about life and sex. To the dying but relentlessly rebellious Sula, Nel remarks that: "You can't do it all. You a woman and a colored woman at that. You can't act like a man. You can't be walking around all independent-like, doing whatever you like, taking what you want, leaving what you don't" (142). And Sula retorts that she prefers to and does want to be a man. "I really would act like what you call a man," asserts Sula (143). Sula's NietzscheanOverman-like strong will makes her stand most alone but cannot help her eschew the doom of a witchhunt. Nel's observation points out the fact that gender and race politics underlies the black folks' irrational identification of Sula with evil/witch and their absolute ostracism of Sula.

Sula's social nonconformity and sexual anarchy incur hatred from her town folks-men and women alike. Women hate Sula because she sleeps with their husbands and then dumps them as worthless:

And the fury she created in the women of the town was incredible-for she would lay their 
husbands once and then no more. Hannah had been a nuisance, but she was complimenting the women, in a way, by wanting their husbands. Sula was trying them out and discarding them without any excuse the men could swallow. So the women, to justify their own judgment, cherished their men more, soothed the pride and vanity Sula had bruised. (115)

Out of vanity, Sula's women folks ironically do not condemn their husbands' infidelity against themselves. Men hate Sula most because rumor goes that she sleeps with white men. For Sula's black male folks, it is an unforgivable thing. The following passage illustrates the town folks' strong despite, hatred and impulse to torture Sula:

But it was the men who gave her the final label, who fingerprinted her for all time. They were the ones who said she was guilty of the unforgivable thing-the thing for which there was no understanding, no excuse, no compassion. The route from which there was no way back, the dirt that could not ever be washed away. They said that Sula slept with white men. It may not have been true, but it certainly could have been. She was obviously capable of it. In any case, all minds were closed to her when that word was passed around. It made the old women draw their lips together; made small children look away from her in shame; made young men fantasize elaborate torture for her-just to get the saliva back in their mouths when they saw her. (112-13)

What is manifested hereby is the moral panic which leads to witch-hunt. All the people in the Bottom-men and women, the old and the young alike-are involved in the mass hysteria over the fact/rumor that Sula sleeps with white men. Sula's male folks even imagine the scene of Sula sleeping with some white man. "Every one of them imagined the scene, each according to his own predilections-Sula underneath some white man-and it filled them with choking disgust. There was nothing lower she could do, nothing filthier" (113). The town folks' mass hysteria prevents them from seeing the truth that race and gender politics generate their bias and subsequent moral panic. Miscegenation and interracial sex have already made history in black community. Town folks in the Bottom deny Sula any tolerance because she is a colored woman and she makes herself a black Byronic heroine. Like Nel, the narrator expands on the gender and race politics in the town folks' condemnation and victimization of Sula:

The fact that their own skin color was proof
that it had happened in their own families
was no deterrent to their bile. Nor was the
willingness of black men to lie in the beds of
white women a consideration that might lead
them toward tolerance. They insist that all
unions between white men and black women
be rape; for a black woman to be willing was
literally unthinkable. In that way, they regarded
integration with precisely the same venom that
white people did. (113) Black men allow themselves to sleep with white women but despise the sexual union between Sula and any white man. This mindset articulates male privileges and simultaneously gives full expression to the gender and race politics which delimits Sula's female body, sexuality and subjectivity. Therefore, Sula's body is both a gendered and racialized body.

A comparison of Sula (a female sexual anarchist) and Ajax (a male sexual anarchist) also shows that different body politics for man and woman determines different identity politics. Like Sula, Ajax practices sexual anarchy. Ajax keeps a lot of women at the same time and is very nice to women albeit he believes that he has never met any interesting woman in his life. As his women fight murderous battles over him, Ajax looks on with indifference:

\begin{abstract}
Ajax was very nice to women. His women, of course, knew it, and it provoked them into murderous battles over him in the streets, brawling thick-thighed women with knives disturbed many a Friday night with their bloodletting and attracted whooping crowds. On such occasions Ajax stood, along with the crowd, and viewed the fighters with the same golden-eyed indifference with which he watched old men playing checkers. (125-26)
\end{abstract}

Ajax keeps women but he does not want to be nailed to any woman. This philosophy finds resonance in Sula's 
and thus explains why Ajax acts against the town folks' witch-hunt and goes after the ostracized Sula. For Ajax, Sula is his ideal partner in defying social mores and practicing sexual autonomy/anarchy:

He had heard all the stories about Sula, and they aroused his curiosity. Her elusiveness and indifference to established habits of behavior reminded him of his mother, who was as stubborn in her pursuits of the occult as the women of Greater Saint Matthew's were in the search for redeeming grace. So when his curiosity was high enough he picked two bottles of milk off the porch of some white family and went to see her, suspecting that this was perhaps the only other woman he knew whose life was her own, who could deal with life efficiently, and who was not interested in nailing him. (127)

Nevertheless, Ajax runs away from Sula when he detects that Sula seems to get serious about their relationship and shows a tendency to possess him. Both Sula and Ajax practice sexual autonomy/anarchy; but biased gender ideology establishes different fates for them. Sula suffers and withstands her black folks' condemnation whereas Ajax walks away free of trouble. Evidently, Sula's body is a gendered body.

My foregoing assertion that patriarchal gender ideology underpins black folks' mass hysteria against Sula makes up for the critical lacuna in Susan Neal Mayberry's "Something Other Than Family Quarrel: The Beautiful Boys in Morrison's Sula." Assuming Morrison's novel as a denunciation of the dichotomous thoughts of masculinity/femininity, good/evil, Mayberry gives high praise to Ajax:

Unlike Jude, who uses Nel to complete him, and unlike Nel and Sula, who complete each other, Ajax is whole within himself. Integrating the feminine with the masculine, able to connect yet be separate, his complex wholeness draws Sula's attraction and respect; she recognizes the gold leaf underneath the blackness of his face, and underneath that the cold alabaster, and underneath that the fertile loam. In Morrison's complicated world created to resist easy definitions of good and evil, Ajax is no more a villain for leaving Sula than Sula is a villain for having this insight: "Soon I would have torn the flesh from his face just to see if I was right about the gold and nobody would have understood that kind of curiosity." (529)

According to Mayberry, Ajax is complete within himself and thus empowers himself to move around free of responsibility and of trouble. Nevertheless, Mayberry is oblivious of Morrison's design to have Sula speak out, right before she dies, her resentment of the male privilege over life and sexuality. When Nel tells the dying Sula that, as a black woman, Sula cannot do whatever she likes, take whatever she wants and leave whatever she does not, Sula challenges Nel: "You say I'm a woman and colored. Ain't that the same as being a man?" (142). Sula's rhetorical question to Nel brings to the fore the social constraints, gender inequality and injustice that she, an emblem of black women, has been suffering. Moreover, Mayberry's observation fails to answer why Sula-as independent, fearless and adventuresome as Ajax-is condemned whereas Ajax, just like all the other infidel men, is not. Instead, Nel's words to the dying Sula succinctly lay bear the sexual and racial prejudice against a liberated woman like Sula: "You can't do it all. You [are] a woman and a colored woman at that. You can't act like a man" (142). In the same vein, Nel's admonishment about Sula's iconoclastic attitude towards gender and race lines and Sula's bitterness over male privileges also challenge Maggie Galehouse's assertion that "Morrison's point in her description of her protagonist supersedes questions of gender and race" (339). Sula's liberated body is made flesh, evil and dangerous whereas Ajax's is seen as common, normal and acceptable simply because the former is a colored woman while the latter is a man. In short, gender and race bias play the key roles in the black folks' judgment of Sula's (mis)conducts and their eventual flesh-ization of Sula as evil and dangerous.

\section{Flesh-ized Sula as a Witch and Scapegoat}

With her mind set to enjoy sex, Sula grows up not only to enjoy the pleasure of flesh but also to translate her nihilism into her sexuality and life philosophy. Two events in Sula's childhood lead Sula to develop a 
nihilistic philosophy toward sex and life. The first event occurs when Sula is eleven years old. Hannah once chats with her friends complaining about the difficulty of rearing a child and pronounces that "I love Sula, I just don't like her" (57). Unfortunately, Sula overhears the remark and is much hurt by her mother's statement. From Hannah's hurtful pronouncement, Sula learns that there is no one that she can count on. The second event is Sula's accidental drowning of Chicken Little in the river where Sula, Nel and Chicken Little play together. From the little black boy's death, Sula learns that there is no self to count on either:

Sula was distinctly different. Eva's arrogance and Hannah's self-indulgence merged in her and, with a twist that was all her own imagination, she lived out her days exploring her own thoughts and emotions, giving them full reign, feeling no obligation to please anybody unless their pleasure pleased her. As willing to feel pain as to give pain, to feel pleasure as to give pleasure, hers was an experimental life-ever since her mother's remarks sent her flying up those stairs, ever since her one major feeling of responsibility had been exorcised on the bank of a river with a closed place in the middle. (118)

Since then, Sula leads an experimental life with no center or speck around which she can grow. "For that reason she felt no compulsion to verify herself-to be consistent with herself" (119). Sula becomes a pariah, and she knows it. Sula translates her nihilism into her sexuality by sleeping with men as frequently as she could. However, a paradox underlies Sula's philosophy about sex and life. Though Sula gets pleasure and joy in sex, sex is the only place where she can find what she is looking for-misery and the ability to feel deep sorrow in life. And it is by sexual pleasure that Sula tastes the nada of existence:

And there was utmost irony and outrage in lying under someone, in a position of surrender, feeling her own abiding strength and limitless power. But the cluster did break, fall apart, and in her panic to hold it together she leaped from the edge into soundlessness and went down howling, howling in a stinging awareness of the ending of things: an eye of sorrow in the midst of all that hurricane rage of joy. There, in the center of that silence was not eternity but the death of time and a loneliness so profound the word itself had no meaning. (123)

As a result, Sula translates her nihilism into her deliberate transgression of all moral norms and rebellion against all social mores.

However, Sula's black folks do not and cannot understand the existential nihilism expressed in Sula's sexual autonomy/anarchy and social nonconformity. As a woman libertine, Sula is like "an artist with no art form" and becomes a danger to her black community (121). In the beginning, the black folks in the Bottom call Sula $a$ roach when she defies the traditional female role of a caretaker of the elderly and puts her grandmother Eva in a nursing home. The black folks call Sula $a$ bitch when she challenges patriarchal constraints on women, asserts sexual autonomy/anarchy and lies with any man-including Jude, the husband of Sula's best friend Nel. Ultimately, the black folks call Sula $a$ witch when her community suffers decline and unemployment and the rumor goes around that Sula sleeps with white men. Sula further expresses her resolute disregard of the social norms and mores when she goes as far as attending a supper for an old folk's funeral without underwear. This radical (mis)conduct makes the town folks believe that she is laughing at their God. As a whole, Sula's liberated and libertine life makes her "the witch/bitch" and "the common enemy" of her folks who have been suffering individual and collective misfortunes. The black folks therefore flesh-ize Sula's body and associate her body to mysticism and evil. Black folks' fear of Sula's mysterious evil power first manifests itself when Sula returns to the Bottom in Medallion ten years after she left her hometown for college. Coincidentally, there is a massive surge of robins dying when Sula just arrives at the Bottom:

Accompanied by a plague of robins, Sula came back to Medalllion. The little yam-breasted shuddering birds were everywhere, exciting very small children away from their usual welcome into a vicious stoning. No body knew why or from where they had come. What they did know was that you couldn't go anywhere 
without stepping in their pearly shit, and it was hard to hang up clothes, pull weeds or just sit on the front porch when robins were flying and dying all around you. (89)

Moreover, Sula's social and moral (mis)conducts happen during the time that her black folks in the Bottom have been suffering the worst decline and unemployment as a consequence of urbanization. Therefore, "[e]verybody remembered the plague of robins that announced her return" (112). In addition to such name-callings as roach, bitch and witch, Sula's folks believe that Sula embodies evil and danger. The town folks attribute to Sula all the misfortunes-individual and collective-in their community. The first instance is Teapot's accident. The five-year-old boy Teapot knocks at Sula's door to ask if she has any bottles to give away. When Sula says no and Teapot turns around to go away, the boy falls down the steps and gets hurt. Betty, Teapot's mother, goes around telling and convincing people that Sula is to blame for Teapot's fall and injury. Another personal misfortune happens to Mr. Finley. It has been Mr. Finley's habit to suck chicken bones for thirteen years. One day, Sula passes Mr. Finley, who is sitting on his porch and sucking chicken bones, when the old man looks up at Sula, chokes on a bone and dies on the spot. Again, the town folks associate Finley's death with Sula's evil force. Moreover, Sula is nearly thirty, but she does not look her age. Sula remains young and very beautiful without developing any ring of fat on her waist or pocket at the back of her neck. The black folks attribute Sula's beauty and youth to her use of necromancy. The following quotation shall illustrate that town folks in the Bottom spin tall tales to convince each other of Sula's mysterious and evil power and thus to present Sula as an avatar of a witch:

Among the weighty evidence piling up was the fact that Sula did not look her age. She was near thirty and, unlike them, had lost no teeth, suffered no bruises, developed no ring of fat at the waist or pocket at the back of her neck. It was rumored that she had had no childhood diseases, was never known to have chicken pox, croup or even a runny nose. She had played rough as a child-where were the scars?
Except for a funny-shaped finger and that evil birthmark, she was free of any normal signs of vulnerability. Some of the men, who as boys had dated her, remembered that on picnics neither gnats nor mosquitoes would settle on her. Patsy, Hannah's one-time friend, agreed and said not only that, but she had witnessed the fact that when Sula drank beer she never belched. (115)

Town folks' mass hysteria toward Sula's nonconformist (mis)conducts reflects de facto their subconscious drive to find a cause-but ironically a scapegoat-for their misfortunes. According to Wolfgang Behringer's analysis of witch-hunts in history, people hunt witches because they hold the belief that a person conjuring or possessing evil force brings them misfortunes and harms. Behringer describes this groundless belief as follows:

There are evil forces around, and they try to
cause harm. Some people, who are essentially
anti-social, either incorporate such forces
involuntarily, or form alliances with these
forces intentionally in order to inflict harm by
mystical means, mostly on their relatives or
neighbours [...]. In this capacity they manage
to induce illness and death, to destroy livestock
and crops. (12-13)

Moreover, people who suffer most severely the pains of displacement created by structural change tend to be drawn most readily into witch-hunts (26). Behringer's observations are helpful in explaining the disadvantaged and disempowered black folks' collective subconsciousness and mass hysteria in attributing to Sula their ongoing communal decline and prolonged unemployment.

As a social nonconformist and sexual anarchist, Sula no doubt makes herself fall prey to the irrational witch-hunt of her town folks. Sula's folks subconsciously flesh-ize her as evil and identify her with a witch and thus as the cause of their community's illness. Therefore, the folks lay broomsticks across their doors at night and sprinkle salt on porch steps to prevent Sula's evil force from getting into their houses. Believing their God has His way, Sula's folks do not commit "mob kill" as people in the sixteenth, seventeenth century did to an 
evil witch. Nevertheless, all the town folks absolutely isolate Sula as an alternative way to castigate the witch and exorcise the evil of their Bottom.

Their conviction of Sula's evil changed them in accountable yet mysterious ways. Once the source of their personal misfortune was identified, they had leave to protect and love one another. They began to cherish their husbands and wives, protect their children, repair their homes and in general band together against the devil in their midst. (117-18)

Accordingly, folks in the Bottom welcome Sula's death as the best news they have ever had since unemployment reached them three years before. Upholding the view that their God has His mighty thumb eventually at Sula's throat, Sula's town folks look forward to having a promising prospect for their future. With Sula the evil/danger gone, they naively assume that everything will go well. They take the rumor for truth that the government will hire black workers for the construction of the tunnel; yet, they have not sensed that racist bigotry keeps deterring the "official" plan and prolongs their unemployment. Without Sula's mockery at tradition, mores and norms, black folks in the Bottom relapse into their original relationship betwixt and between themselves:

A falling away, a dislocation was taking place. Hard on the heels of the general relief that Sula's death brought a restless irritability took hold. [...] Other mothers who had defended their children from Sula's malevolence (or who had defended their positions as mothers from Sula's scorn for the role) now had nothing to rub up against. The tension was gone and so was the reason for the effort they had made. Without her mockery, affection for others sank into flaccid disrepair. Daughters who had complained bitterly about the responsibilities of taking care of their aged mothers-in-law had altered when Sula locked Eva away, and they began cleaning those old women's spittoons without a murmur. Now that Sula was dead and done with, they returned to a steeping resentment of the burdens of old people. Wives uncoddled their husbands; there seemed no further need to reinforce their vanity. (153-54)
In short, not one single positive change has happened to people's mindset and life in Sula's black community.

Sula is a rebel; but her folks take her for a devil. Sula demonstrates her nihilism with her defiance against all moral norms and social mores and with her resolute assertion of sexual autonomy/anarchy. Sula makes herself a black Byronic heroine and accordingly creates the pretext for her folks to victimize her. As a result, Sula is flesh-ized as "the bearer of pleasure and desire," to borrow Foucault's words, and is thus identified as an evil and a witch. What is at issue here is why Sula's folks do not flesh-ize nor condemn men who also assert sexual autonomy/anarchy. What Sula's folks do not recognize about their mass hysteria against Sula is that they construct and (en)gender Sula's body when they flesh-ize her as abnormal/evil/ bitch/witch. Morrison's remark in her 1976 talk with Robert Stepto exemplifies well how gender politics delimits the doom for Sula:

She is a masculine character in that sense. She will do the kind of things that normally only men do, which is why she's so strange. She really behaves like a man. She picks up a man, drops a man, the same way a man picks up a woman, drops a woman. And that's her thing. She's masculine in that sense. She's adventuresome, she trusts herself, she's not scared, she really ain't scared. And she is curious and will leave and try anything. So that quality of masculinity-and I mean this in the pure sense-in a woman at that time is outrage, total outrage. She can't get away with that-unless she were in this sort of strange environment, this alien environment-for the normal-which would be the theater world, in which you realize, the people are living, even there, by laws. (26-27)

Apparently, androcentric gender ideology is complicit with designating different lives and identities for Sula, a token of liberated women, and for the privileged men. In Volatile Bodies: Toward a Corporeal Feminism, Elizabeth Grosz points out the constructive nature of the body as she asserts that the body is "a site of social, political, cultural, and geographical inscriptions, production, or constitution" and "a cultural product" (23). Grosz's remark on the constructiveness of an 
individual's body finds its philosophical resonance in Foucault's observation of the flesh-ization of the body as evil and dangerous. An individual is flesh-ized as evil and dangerous because s/he rebels against the demand of morality and conformity, remarks Foucault. In this sense, the body is an arena for power contestation between an individual who struggles for self-definition and a society which demands discipline and conformity. Unfortunately, the black folks' discrimination against Sula negates her autonomy claim over her body and life. As a social nonconformist and sexual dissident, Sula's body is deemed abnormal, evil and dangerous. Accordingly, Sula is gendered and racialized as a black witch and symbolically executed. Thus said, this paper concludes that an identification of the body with the flesh, a phallocentric gender ideology and race bias converge into the black folk's identification of Sula with an evil and a witch and their subsequent victimization of Sula as a scapegoat for all the misfortunes happening in their community.

\section{Notas}

1. Emphasis added.

2. Emphasis added.

3. "The Angel in the House" is a poem written by the Victorian poet Coventry Patmore to praise the feminine virtues of his first wife Emily. Since then, the angel in the house becomes the paragon for feminine submissiveness, docility, obedience and self-sacrifice. Abiding by patriarchal gender ideology, a woman must mold herself on this paragon in order to make a good woman.

\section{References}

Behringer, Wolfgang. Witches and Witch-Hunts: A Global History. Cambridge: Polity Press, 2004. Print.

Bergenholtz, Rita A. "Toni Morrison's Sula: A Satire on Binary Thinking," African American Review 30.1 (1996): 88-98.

Bryant, Cedric Gael. "The Orderliness of Disorder: Madness and Evil in Toni Morrison's Sula, Black American Literature Forum 24.4 (1994): 731-45.

Douglas, Mary. Purity and Danger: An Analysis of the Concepts of Pollution and Taboo. London \& New York: Routledge, 1991. Print.
Foucault, Michel. Abnormal. Trans. Graham Burchell. New York: Picador, 2003. Print.

Galehouse, Maggie. “New World Woman': Toni Morrison's Sula." Papers on Language and Literature: A Journal for Scholars and Critics of Language and Literature 35.4 (1999): 339-62. Print.

Grosz, Elizabeth. Volatile Bodies: Toward a Corporeal Feminism. Bloomington \& Indianapolis: Indiana UP, 1994. Print.

Hooks, Bell. Black Looks: Race and Representation. Boston, MA: South End Press, 1992. Print.

Mayberry, Susan Neal. "Something Other Than a Family Quarrel: The Beautiful Boys in Morrison's Sula." African American Review 37.4 (2003): 517-33. Print.

Morrison, Toni. Sula. 1973. London: Vintage, 1998. Print. "Unspeakable Things Unspoken." Within the Circle: An Anthology of African American Literary Criticism from the Harlem Renaissance to the Present. Ed. Angelyn Mitchell. Durham \& London: Duke UP, 1994. 368-98. Print.

Okonkwo, Christopher N. "A Critical Divination: Reading Sula As Ogbanje-Abiku," African American Review 38.4 (2004): 651-68.

Stepto, Robert. "Intimate Things in Place: A Conversion with Toni Morrison." Conversions With Toni Morrison. Ed. Danille Taylor-Guthrie. Jackson: UP of Mississippi, 1994. 10-29. Print.

Recebido em: 04/06/2015 Aceito em: 09/07/2015 